Historia
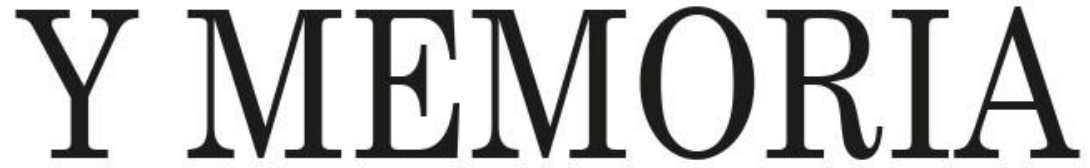

ISSN: 2027-5137

Enero - Junio, Año 2021 - Tunja, Colombia

"Matanza, Pillaje y destrucción»: aspectos sociales de la Revolución mexicana vistos desde Colombia, 19101917

https:/doi.org/10.19053/20275137.n22.2021.10878

José David Cortés Guerrero

Páginas 245-284

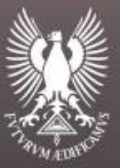




\title{
«Matanza, pillaje y destrucción»: aspectos sociales de la Revolución mexicana vistos desde Colombia, 1910-1917*
}

\author{
José David Cortés Guerrero ${ }^{1}$ \\ Universidad Nacional de Colombia- \\ Sede Bogotá-Colombia
}

Recepción: 17/04/2020

Evaluación: 13/06/2020

Aprobación: 13/08/2020

Artículo de Investigación e Innovación

https:/doi.org/10.19053/20275137.n22.2021.10878

\section{Resumen}

El artículo muestra cómo fue interpretada, en cuanto a aspectos sociales, la Revolución Mexicana en Colombia, entre 1910 y 1917. Esto significa mostrar los imaginarios que se crearon en el país en tres puntos específicos: las causas sociales de la Revolución; los líderes sociales de la misma, esencialmente Pancho Villa y Emiliano Zapata; y el pueblo en armas. En los dos últimos se observan las imágenes peyorativas que se construyeron sobre la Revolución, esto con el objeto de deslegitimar cualquier reivindicación de los sectores populares.

\footnotetext{
* El artículo es resultado del proyecto de investigación La Revolución mexicana vista por los colombianos, 1910-1917, apoyado por la convocatoria de investigación Orlando Fals Borda-2017, de la Facultad de Ciencias Humanas, Universidad Nacional de Colombia, sede Bogotá. Código Hermes 39254. Agradezco a las auxiliares de investigación, las estudiantes de historia Nathalia Zamora y Camila Jaimes.

1 Doctor en Historia, Profesor asociado, Departamento de Historia, Universidad Nacional de Colombia, sede Bogotá. Últimas tres publicaciones: «Religión e Iglesia en el proceso independentista colombiano," en Bicentenario de la Independencia de Colombia, 1810-1830 y la fundación de la República, ed. Daniel Raisbeck (Bogotá: Banco de la República, 2019), 216-225; «Estado-Iglesia en Colombia en el siglo XIX,» en La República, 1819-1880, ed. Pablo Rodríguez (Bogotá: Universidad del Rosario, 2019), 111-120; "Tolerancia religiosa e inmigración. México y Nueva Granada a finales de la década de 1840," Anuario de Historia Regional y de las Fronteras Vol.23, n 2 (2018): 51-84, DOI: https://doi.org/10.18273/revanu.v23n2-2018002. $ه$ jdcortesg@unal.edu.co () http://orcid.org/0000-0002-2581-7442.
} 
Las interpretaciones e imágenes que se elaboraron sobre la Revolución en Colombia lo fueron por miedo al contagio y al mal ejemplo, por ello se observa que la Revolución fue vista, mayoritariamente, como una confrontación en donde reinaban la matanza, la destrucción y el pillaje.

Palabras Clave: Revolución mexicana; Pancho Villa; Emiliano Zapata; Colombia-historia-1910-1917; Bandidismo.

«Massacre, pillage and destruction»: social aspects of the Mexican revolution from a Colombian perspective, 1910-1917

\begin{abstract}
This article shows how the Mexican Revolution, between 1910 and 1917, was interpreted, as regards social aspects, in Colombia. This means showing the beliefs that were created in three specific points: the social causes of the revolution, its social leaders, in particular Pancho Villa and Emiliano Zapata, and the people in arms. In the last two, pejorative images of the revolution are observed, with the objective of delegitimizing any grievance of the popular sectors. The interpretation and images elaborated about the revolution, in Colombia, were a consequence of the fear of its spreading and of the bad example it set, and therefore, it is observed that the revolution was seen, mainly, as a confrontation where massacres, destruction and pillage ruled.
\end{abstract}

Key words: Mexican Revolution, Pancho Villa; Emiliano Zapata; Colombia-history-1910-1917; banditry.

«Carnage, pillage et destruction»: aspects sociaux de la Révolution mexicaine vus depuis la Colombie, 19101917

\title{
Résumé
}

Cet article montre comment les aspects sociaux de la Révolution mexicaine ont été interprétés en Colombie entre 
1910 et 1917. Cela nous fait revenir sur les imaginaires qui ont été créés en Colombie, et que l'on peut associer à trois point spécifiques: les causes sociales de la Révolution; ses leaders sociaux (notamment Pancho Villa et Emiliano Zapata); et le peuple en armes. À ce propos, on voit des images méprisantes sur la Révolution qui visaient à rendre illégitime toute revendication des secteurs populaires. Les interprétations et les images qui ont été élaborées sur la Révolution en Colombie étaient fondées sur la peur de la contagion et du mauvais exemple, et c'est pourquoi on voit que la Révolution a été vue notamment comme une confrontation dominée par le carnage, la destruction et le pillage.

Mots-clés: Révolution mexicaine, Pancho Villa, Emiliano Zapata, Colombie, histoire, banditisme.

\section{Introducción}

En este artículo mostraremos cómo se leyó la Revolución mexicana en Colombia mientras se presentaba el proceso histórico, es decir, entre 1910 y 1917; sin embargo, esto es muy amplio. Nos centraremos en cómo fue interpretado el tema social en la Revolución. Para ello dividimos el texto en tres partes. En la primera vemos cómo se determinaron las causas sociales de la Revolución, esto es, por ejemplo, la pobreza de la población. En la segunda mostraremos las lecturas que existían sobre los líderes sociales del movimiento, aquellos que desde temprano fueron reconocidos en ese rol. Nos referimos esencialmente a Emiliano Zapata y a Pancho Villa. En la tercera parte veremos las interpretaciones que se construyeron sobre el pueblo que participaba en la Revolución, especialmente, aunque no de forma exclusiva, quienes integraban los ejércitos revolucionarios.

En la primera parte del artículo puede verse cómo las causas de la Revolución mostraban a un pueblo explotado y abatido por el régimen porfirista y los poseedores del capital. En contraste, las partes segunda y tercera muestran al pueblo revolucionario delincuente, que deseaba saciar su sed de venganza contra los sectores acomodados de la sociedad. Así, 
las notas que aparecían en la prensa eran, en su gran mayoría, informando sobre robos, saqueos, violaciones y asesinatos, y muy poco se publicaban textos de análisis e interpretación del problema mexicano. Esta paradoja, creemos, se explica por el temor al pueblo sublevado y por la solidaridad que despertaban las élites mexicanas entre los generadores de opinión pública colombiana. En este sentido, si bien hay conmiseración por el pueblo oprimido y hasta pena por los males que padecía, primaba el desprecio y el miedo al pueblo en revolución. Es decir, se veían las causas objetivas del estado calamitoso que vivía la mayoría de la población, pero se creía que ello no era causal para que esa población se sublevara contra el orden social establecido. Lo anterior nos permite plantear la hipótesis de que esa paradoja de describir las condiciones sociales previas a la Revolución, pero cuestionar y criticar al pueblo en el movimiento revolucionario, se debía a que se estaba leyendo la Revolución mexicana desde la óptica de la historia colombiana, lo que significaba que era posible que lo que estaba pasando en México sucediera en Colombia, por lo que era necesario condenar cualquier insurrección. Una posible insubordinación popular en Colombia cuestionaría dos escenarios: el imaginario que se había construido, desde la década de 1830, sobre el civilismo en el país, es decir, gobernado por políticos que respetaban las reglas del juego democrático; y sobre la época de paz que se vivía después de la guerra de los Mil Días (1899-1902) ${ }^{2}$. En este orden de ideas se creía que la Revolución mexicana podía contagiar al resto del continente, incluyendo Colombia, por lo que era necesario estar atentos ${ }^{3}$. En Colombia, la idea de contagio se

\footnotetext{
$2 \mathrm{El}$ civilismo lo entendemos no como la ausencia de conflicto. Colombia tuvo, en el siglo XIX, por lo menos ocho guerras civiles generales, sin contar las de independencia y las regionales. Es, más bien, la forma como la elite «respetaba» el juego democrático, los tres poderes eran elegidos, cumplían sus periodos, y entregaban el poder, evitándose que alguien, al estilo de Porfirio Díaz en México, intentara perpetuarse en la presidencia. Para mirar la lógica de este civilismo decimonónico en Colombia y compararlo con lo que pasaba en México en el mismo siglo XIX, puede verse: José David Cortés Guerrero, «Tolerancia religiosa e inmigración. México y Nueva Granada a finales de la década de 1840," Anuario de Historia Regional y de las Fronteras Vol. 23, n 2 (2018): 57-59, DOI: https://doi.org/10.18273/revanu.v23n2-2018002.

3 En una nota de prensa se indicaba que Rodolfo Espinosa, exembajador de Nicaragua en Washington había salido de México hacia El Salvador para preparar una «nueva revolución contra el presidente Estrada, de Guatemala». «México», El Liberal, Bogotá,
} 
fundamentaba en el imaginario basado en el miedo al pueblo. Es decir, sin llegar a afirmar que en el país se presentaban las mismas condiciones sociales que en México, sí se creía que el pueblo podría imitar el levantamiento en armas.

El artículo abarca el período comprendido entre 1910 y 1917, entre el Plan de San Luis y la promulgación de la constitución. En ese lapso, lo que va desde noviembre de 1910 hasta mediados de 1914 fueron los años en el que mayor interés se le prestó a la Revolución en Colombia. Pero desde el inicio de la Primera Guerra Mundial esa atención disminuyó considerablemente como puede verse a continuación: "La sensación producida por la guerra europea ha hecho que todos nos olvidemos de la situación de México, país al cual se le espera una resurrección material y moral, después del quebramiento causado por la guerra» ${ }^{4}$. Sabemos que esa resurrección no fue inmediata, incluso el año de 1915 puede ser el de mayor conflicto bélico en la Revolución ${ }^{5}$. Ese desvío en el objeto de atención por parte de la prensa era claro, como lo muestran periódicos colombianos: «el débil eco de los cañonazos de la anarquía mexicana [había] sido superado por el estruendo de la conflagración europea» ${ }^{6}$.

En cuanto a la fuente para la elaboración del artículo es la prensa colombiana del período. Como podrá verse, se ha hecho una revisión de periódicos de las diversas regiones del país, tanto en las grandes ciudades como en pequeñas, por ejemplo, Bogotá, Antioquia, Costa Caribe, Eje Cafetero, Occidente y centro-nororiente. Allí encontramos artículos de opinión y análisis, así como notas cablegráficas provenientes de México y Estados Unidos, y estas notas comentadas por los editores de los periódicos colombianos.

24 de abril de 1911, 3. Es decir, tres países centroamericanos, además de México, que se verían envueltos en una revolución.

4 «Situación de Méjico», El Liberal, Bogotá, 26 de septiembre de 1914, 2.

5 Pedro Salmerón Sanginés, 1915. México en guerra (México: Planeta, 2015); Pedro Salmerón Sanginés, «Los historiadores y la guerra civil de 1915. Origen y persistencia de un canon historiográfico,» Historia Mexicana Vol. 58, n 4 (2009): 1305-1368.

6 «Porfirio Díaz», La Tribuna, Bogotá, 5 de julio de 1915, 1. 
He optado por periódicos de todo el país por varios motivos. Primero, porque generalmente, cuando se estudia un problema histórico y se alude a toda Colombia, esta se reduce a lo que pasaba en Bogotá, por lo que si hablamos de cómo fueron vistas algunas características de la Revolución mexicana en Colombia es necesario tomar una muestra representativa del país. Segundo, porque resulta relevante ver cómo en periódicos de lugares distintos a Bogotá, poco conocidos y con circulación restringida, pareciera existir algún interés por interpretar la Revolución.

En el artículo, los periódicos, independientemente de sus posturas partidistas, ideológicas, religiosas, y de su lugar de publicación, son tratados de igual manera. Esto porque se observa que, a pesar de esas posturas y diferencias, los unía la crítica a las condiciones sociales de pobreza de la mayoría de los mexicanos, así como la crítica y condena a la población en armas y a los líderes sociales de la Revolución. Podría pensarse que periódicos de corte liberal (El Tiempo de Bogotá, El Espectador de Bogotá y Medellín, El Liberal, ya sea de Bogotá o de Bucaramanga, El Correo Liberal de Medellín, Gil Blas de Bogotá) eran más propensos a tener una visión menos peyorativa sobre el pueblo, pero en poco se diferencia esa visión a la que tenían periódicos conservadores y religiosos (Azul de Buga, El Baluarte de Chiquinquirá, La Semana Católica de Cali, El Evangelista Cristiano de Bogotá, El Cometa de Popayán).

Muchos tópicos de la Revolución mexicana pueden ser vistos a partir de la lectura que sobre ella tuvieron los colombianos: el caudillismo, las características del pueblo mexicano, el problema agrario, la situación de los indígenas, la influencia e intervención extranjera en México, las lecturas sobre la barbarie del conflicto armado, entre otros. Llama poderosamente la atención que tres temas que parecerían relevantes, el problema agrario, la situación indígena y la explotación de recursos como el petróleo, después de la revisión de fuentes, fueron abordados en la prensa de manera precaria. 
Como mencionamos atrás, en este artículo entendemos la Revolución mexicana como el proceso histórico comprendido entre el Plan de San Luis y la promulgación de la Constitución Política de 1917. Esto es, desde el llamado a levantarse en armas el 20 de noviembre de 1910 hasta el 5 de febrero de 1917. La Revolución comenzó como un problema eminentemente político ligado con la sucesión presidencial, lo que puede verse en el llamado a armas por parte de Francisco I. Madero en el citado Plan. A la par, y con el paso del tiempo, sectores políticos y sociales se sumaron al movimiento buscando satisfacer reivindicaciones, entre ellas el acceso a la tierra y a los recursos naturales.

Una vez Díaz renuncia en mayo de 1911, Madero es elegido presidente, ejerciendo este cargo hasta que fue derrocado y asesinado, junto con su vicepresidente, José María Pino Suárez, en la Decena Trágica, esto es entre el 9 y 19 de febrero de 1913. Victoriano Huerta, viejo militar porfirista, jefe del golpe, conduce el país hasta su renuncia el 15 de julio de 1914. En ese lapso, el ejercito federal hizo frente a la unión de ejércitos revolucionarios -carrancistas, villistas, zapatistas, entre otros-, además de la intervención estadounidense en Veracruz. La renuncia de Huerta y el fracaso de la Convención de Aguascalientes en noviembre de 1914, en donde los líderes revolucionarios no se pusieron de acuerdo en cuanto a la conducción del país, llevó a México a dos años de guerra sangrienta que enfrentó a los antiguos aliados antiporfiristas, lo que significó la derrota de los ejércitos con connotaciones más sociales, estos eran los villistas y zapatistas, y a que los grupos menos radicales de la Revolución, ligados a Venustiano Carranza, quien fue elegido presidente del país, y ostentó este cargo hasta su asesinato el 21 de mayo de 1920, redactaran la constitución de 1917 y le dieran rumbo al proceso posrevolucionario ${ }^{7}$. Es de anotar que estos matices, mostrados aquí de manera rápida y grosso modo, no pueden ser distinguidos al leer la prensa colombiana

7 Para una aproximación a la Revolución mexicana, en más de mil páginas, puede verse Alan Knight, La Revolución mexicana (México: Fondo de Cultura Económica, 2010). 
sobre la Revolución. Es decir, la prensa muestra el proceso como si fuera homogéneo y evita exponer su complejidad. En las páginas de los periódicos pueden leerse notas y noticias carentes de contexto, pero que cumplían con el objeto de mostrar una situación caótica en México.

En cuanto a Colombia, las dos primeras décadas del siglo XX -después de la separación de Panamá (1903)-, sobre todo la de 1910, presentan serios vacíos historiográficos. El gobierno de Rafael Reyes, proyectado para el período 19041910, y posteriormente llamado el Quinquenio (1905-1909), terminó abruptamente porque Reyes comenzó a mostrar serios indicios de autoritarismo cuando amplió su período de gobierno a diez años, favoreciendo con negocios a amigos y familiares, buscando emular a uno de sus referentes, el presidente mexicano Porfirio Díaz. Conservadores y liberales presionaron a Reyes, quien renunció en 1909, dejando a Jorge Holguín encargado de la jefatura de Estado, quien a su vez la cedió al vicepresidente Ramón González Valencia para terminar el período. En 1910, una Asamblea Constituyente designó como presidente al antioqueño Carlos E. Restrepo, líder de la coalición bipartidista denominada republicana, además de reducir el tiempo de mandato a cuatro años. Así, Restrepo gobernó el país entre 1910-1914. A Restrepo lo sucedió en la administración, el conservador Vicente Concha (1914-1918).

El lapso de 1910 a 1918, en la República Conservadora (1880-1930), es sobre el que menos se ha ahondado. A diferencia de la primera década del siglo XX, y los agitados años veinte, ese período proyecta la imagen de paz y tranquilidad, lo que les permitió a políticos y publicistas comparar y contrastar a una supuesta Colombia pacífica con el convulsionado México. Considero que la idea de quietud es poco atractiva para los historiadores colombianos, por lo que han descuidado estudiar con mayor ahínco esa parte de nuestra historia. Así, lo que se sabe de la segunda década del siglo pasado se da por sentado y se convierte en canon de interpretación, de tal forma que se tiende a reproducir lo que sobre el período se viene afirmando desde, por lo menos, la década de 1960; sin embargo, es 
necesario que cuestionemos el postulado sobre la tranquilidad de la década de 1910 que se refleja en vacíos historiográficos, y por medio de estudios monográficos, como este artículo, contribuyamos a explicar de manera más profunda aquel período. De esta forma, acercarse a aquella década, a partir del estudio de un proceso extranjero, la Revolución mexicana, puede ayudar a nutrir una agenda de investigaciones.

Así como atrás explicamos lo que es el artículo es necesario indicar lo que no es. El artículo no es una revisión de la manera como el ideario revolucionario mexicano (y también el postrevolucionario) incidió desde $1918 \mathrm{y}$, especialmente en la República Liberal (1930-1946), en los imaginarios e idearios de los grupos políticos colombianos. Tampoco es una historia de la Revolución mexicana. Por otra parte, sí llamamos la atención en que no se ha estudiado la Revolución mexicana en Colombia como un proceso contemporáneo, es decir, en la década de 1910, esto es como objeto de referencia contemporánea para interpretar la propia historia colombiana.

\section{La cuestión social como causa de la Revolución mexicana}

La idea generalizada que se tiene de la Revolución mexicana es que fue un movimiento popular, mayoritariamente indígena y campesino, que se presentó por la pobreza de la población relacionada con la falta de acceso a los recursos naturales, primordialmente la tierra. En esa idea también se indica que el movimiento, iniciado a finales de 1910, degeneró en caos y anarquía manifestada en actos delictivos cometidos por quienes estaban inmersos en el conflicto armado. En esta parte del artículo queremos mostrar cuáles fueron las lecturas sobre la Revolución enfocadas hacia el aspecto social, incluyendo los factores que pudieron desencadenar la insurrección.

El punto de partida de los análisis y de las interpretaciones estaba en las características del porfiriato. Se indicaba que allí se habían acentuado los problemas de la población. 
Generalmente se cuestionaba la "funesta política porfirista»" a la que se calificaba como una "camisa de fuerza impuesta a un pueblo revolucionario y falto de toda educación cívica» ${ }^{9}$. Se afirmaba que «el indio mexicano era en 1909 idéntico al indio de cuarenta años atrás, en épocas de siniestro vandalaje». En esencia, «era México el mismo país enfermo y viciado» de mediados del siglo XIX, con lo cual se anotaba, aunque sin mayor rigor, que en el porfiriato no se había transformado la mentalidad del mexicano a pesar del «manto extranjero de ferrocarriles, minas y empresas de toda clase» ${ }^{10}$. En esta explicación resalta el coqueteo con el organicismo, emparentado con postulados de Comte y el darwinismo social. México era un cuerpo, organismo vivo, que se enfermaba y degeneraba con el paso del tiempo.

El sociólogo William Ancher, en una nota que fue reproducida en El Tiempo, preguntaba si Porfirio Díaz fue el pacificador de México. Archer respondía que la paz porfiriana era una "comedia [...] representada por una cuadrilla de dominadores a cuya cabeza figuraba ese hombre de genio diabólico, que pudo engañar a todo el mundo» ${ }^{11}$ y que había recibido elogios de los presidentes Theodore Roosevelt y William Taft, entre otros. Se acusaba a Díaz de haber mantenido en la cárcel de Belem más de 5000 presos políticos, además de otras «atrocidades» como las cometidas contra el Club Organizador del partido demócrata, las cuales parecían «leyendas neronianas» ${ }^{12}$.

Siguiendo a Ancher, se indicaba que quien viviera algún tiempo en México notaría la pobreza no de los mendigos sino de quienes tenían trabajo. Su pobreza era mayor que la que se veía en Italia, España e Irlanda: «En ningún país va el pueblo

8 «Méjico y nosotros», El Tiempo, Bogotá, 28 de abril de 1914, 2.

9 «Méjico y nosotros,» 2.

10 «Méjico y nosotros,» 2.

11 «Porfirio Díaz juzgado por William Ancher», El Tiempo, Bogotá, 17 de junio de $1913,2$.

12 «Porfirio Díaz juzgado,» 2.

Sobre Heriberto Barrón, Juan Sánchez Azcona y otros componentes del Club Organizador como sus intereses, puede verse: John Womack jr., Zapata y la Revolución mexicana, $26^{a}$ ed. (México: Siglo XXI Editores, 2004), 23-24. 
tan mal vestido y enseñando más su cuerpo desnudo, ni son tan malas las viviendas» ${ }^{13}$. Las condiciones de trabajo en la ciudad y el campo eran malas, con instrumentos rudimentarios. En ese orden de ideas se advertía que Díaz no fue el que creó esas condiciones, «pero [...] tampoco nada hizo para mejorarlas» ${ }^{14}$.

Contemporáneo a Archer, y en el mismo sentido, el estadounidense John Kenneth Turner escribió: México Bárbaro, un libro que no apareció reseñado en la prensa colombiana. Turner habla de muchos tópicos como la esclavitud indígena, los peones del campo y la pobreza en la ciudad, la destrucción de la oposición política y las huelgas, entre otros tantos. También de cómo la pobreza se extendía a casi toda la población que laboraba, es decir, más de cinco millones de peones ${ }^{15}$.

En el mismo tema grueso de interpretación se reprodujo un artículo de Diego Mendoza publicado en la Revista Nacional de Colombia. En ese texto, Mendoza parafraseaba al ingeniero inglés A. W. Warwick quien se preguntaba si el pueblo mexicano podía progresar. Según él, no podía por varios motivos: primero, el trabajo de los mexicanos era deficiente e inferior. Por ejemplo, en minas de iguales condiciones se empleaba un número diferente de trabajadores; segundo, a pesar de que el $75 \%$ de la mano de obra se dedicaba a labores agrícolas, el país no producía lo que consumía; tercero, el alcoholismo del pueblo; cuarto, la alimentación deficiente y el desdén de los mestizos por el trabajo manual, "cuyo impulso viene de la región alta del cerebro, han retardado el paso delante de aquel pueblo» ${ }^{16}$. Así, el trabajo de la mano de obra extranjera que se reflejaba en la construcción de vías férreas, fábricas, puertos, entre otros, no tenía correspondencia con su par mexicano, es decir, la mano de obra mexicana no tenía las mismas cualidades ni calificaciones de la extranjera. Los

13 «Porfirio Díaz juzgado,» 2.

14 «Porfirio Díaz juzgado,» 2.

15 John Kenneth Turner, México bárbaro (México: Grupo Editorial Tomo, 2010).

16 «El problema de los indios», El Tiempo, Bogotá, 13 de abril de 1914, 2. 
trabajadores mexicanos no tenían «buenos instintos, hábitos de moralidad, noción clara de los deberes, sentimientos religiosos depurados, costumbres cívicas» ${ }^{17}$. Según Warwick, en los primeros años del siglo XX, de los que se hablaba como de gran empuje en México, nada de sus logros había sido hecho por capital e ingeniería mexicanos ${ }^{18}$.

En un artículo sobre la minería en el porfiriato, Brígida von Mentz muestra, empleando dos ejemplos, el contraste entre la minería tradicional que venía desde la Colonia y la moderna. Allí se puede ver la gran variedad en la composición de los trabajadores mineros debido, sobre todo, a las especificidades regionales, y la forma diversa en que las autoridades actuaron para controlar a esos trabajadores ${ }^{19}$.

Así las cosas, se entiende que se explicara que el «problema social de México» estaba en la "mayoría aborigen», definida aquí como los «pelados». Podía verse en cualquier calle de México que pasaban hombres usando "chistera" y "damas a la última moda» mientras que el "pelado» estaba «lleno de microbios», resignado a su suerte ${ }^{20}$. Es decir, parecía existir, según esta explicación, una gran diferencia social y económica entre unos pocos que tenían todo y la gran mayoría que estaba en la pobreza.

En ese orden de ideas, en varias notas periodísticas se buscaba algún tipo de conmiseración o pena por los sectores bajos de esa población. Se indicaba que de los habitantes de México la mitad eran «indios tan puros como los que encontró Hernán Cortés» ${ }^{21}$, millón y medio eran criollos de

17 «El problema de,» 2.

18 «El problema de,» 2. Según Turner, por el mismo trabajo los 150000 trabajadores mexicanos de minas y fundiciones recibían menor jornal que los trabajadores norteamericanos. Los operarios de fábricas de algodón ganaban menos de 60 centavos diarios. Turner, México, 91.

19 Brígida Von Mentz, «Trabajo minero y control social durante el Porfiriato. Los operarios de dos poblaciones contrastantes,» Historia Mexicana, Vol.50, n 3 (2001): 555-607.

20 «A vuelo de pájaro, Méjico», El Debate, Barranquilla, 6 de noviembre de 1912, 2. 21 Ramiro de Maeztu, «Lo de México», El Tiempo, Bogotá, 14 de mayo de 1913, 2. 
"pura sangre española», y los restantes eran mestizos y unos cuantos extranjeros. En cuanto a la población indígena, como la de toda América, se caracterizaba por «su abatimiento, por su temor al blanco, por su incapacidad para el trabajo sostenido por la depresión nerviosa, que sólo se trunca en comunicabilidad histérica al influjo del alcohol» ${ }^{22}$. Según la nota, el problema de México era, entonces, «levantar una raza atrasada», aunque esto no era del todo cierto pues en México algunos indígenas habían sido reconocidos, por ejemplo el «presidente Suárez» (seguramente refiriéndose a Benito Juárez) y «el poeta Altamirano» (refiriéndose, seguramente, a Ignacio Manuel). El problema racial se agravaba con el de la mala distribución de la riqueza puesto que el indio no tenía «otro caudal que sus brazos» ${ }^{23}$.

Siguiendo con este punto, se afirmaba que México era "un país indio». Allí se cuestionaba sobre cómo entender una república en un país en donde ocho millones no sabían leer ni escribir y en donde el viajero encontraba «aldeas y aldeas de habitantes degenerados» ${ }^{24}$, que vivían entre el "terror del sacerdote y la pasión de la bebida fermentada nacional, el pulque» ${ }^{25}$. Los mexicanos indios eran "tímidos, timoratos, sometidos», además vivían en un país en donde había desde climas ecuatoriales hasta alturas de más de tres mil metros, por lo que, según esta explicación, no era posible la cohesión nacional. Para el autor de la nota, cuando faltaba un amo, posiblemente un caudillo como Díaz, se desencadenaban los

22 Maeztu, «Lo de México,» 2.

23 Maeztu, «Lo de México,» 2. Maeztu era un escritor español perteneciente a la Generación del 98.

Para 1910, según el Tercer Censo General de Población, México tenía 15.160.369 habitantes. Véase: Estadisticas históricas de México 2009 (Aguascalientes: INEGI, 2010).

En cuanto a los extranjeros, para 1910 había en el país casi 117.000, la mayoría de ellos provenientes de España, Estados Unidos, Guatemala y China. Cfr. Estados Unidos Mexicanos. Cien años de censos de población (Aguascalientes: INEGI, 1996), 17.

24 «La cuestión mejicana», El Liberal, Bogotá, 29 de abril de 1914, 2.

25 «La cuestión mejicana,» 2. 
apetitos, se organizaban bandos o partidos, y la revolución aparecía para satisfacer intereses personales ${ }^{26}$.

El problema de la pobreza ligada a la falta de acceso a la tierra salía a flote, aunque pocas veces, como una de las causas sociales de la Revolución: «una de las causas de la revolución del año pasado fue el haberse apoderado los grandes propietarios de las tierras de los indígenas» ${ }^{27}$, por lo que el levantamiento prometió la distribución de la tierra, lo que hasta ese momento no se había cumplido. En la misma nota se afirmaba que Pascual Orozco ofreció repartir 14 millones de hectáreas, pero nunca se repartirían extensiones mayores a 200 hectáreas por cabeza. De esta forma, se indicaba, México se decidía «por el régimen de la pequeña propiedad $»^{28}$. Siguiendo con lo anterior, se afirmaba que unos cuantos poseedores de la tierra trataban como siervos a más de once millones de campesinos, lo que hacía aflorar «una lucha entre el feudalismo y sus víctimas» ${ }^{29}$. En una publicación mensual protestante de la ciudad de Bogotá se exponía la misma explicación, indicando que «el territorio nacional ha estado en manos de una o dos docenas nada más de personas, lo cual produjo naturalmente hambre y exasperación en la masa popular» ${ }^{30}$.

Otra causa social que fue señalada como posible de la Revolución mexicana era la composición del pueblo mexicano y su historia. Se quería mostrar que México era, por historia, tierra de "gentes bravas en la guerra". Para reforzar esta idea se usó como pretexto el hallazgo arqueológico de una imagen del dios Huitzilopochtli, y de una leyenda en la que se indicaba que todas las ofrendas a aquél deberían ser sacrificios humanos, lo que hacía deducir que, desde antaño, México vivía cruentas "guerras

26 «La cuestión mejicana,» 2.

27 «Repartición de tierras en Méjico», El Liberal, Bogotá, 8 de junio de 1912, 3.

28 «Repartición de tierras,» 3.

29 «Causas de la guerra en México», El Liberal, Bogotá, 25 de febrero de 1914, 2.

30 «Méjico», El Evangelista Cristiano, Bogotá, enero de 1914, s.p. 
sagradas», lo que otorgó esa «belicosidad impetuosa» reflejada en la Revolución Mexicana ${ }^{31}$.

\section{Los líderes sociales de la Revolución}

En esta parte del artículo veremos cómo fueron percibidos los principales líderes sociales de la revolución, aquellos que desde temprano fueron reconocidos como las cabezas visibles del movimiento, y que, a partir de allí se construyeron imágenes sobre ellos, estos son Emiliano Zapata y Pancho Villa ${ }^{32}$.

Como punto de partida tomamos la columna publicada en el periódico bogotano El Tiempo el 21 de abril de 1915. Allí se indicaba que era lamentable que «una turba de descamisados» llegase a ocupar el Palacio Nacional de la Ciudad de México, como lo habían hecho las fuerzas villistas y zapatistas después del Pacto de Xochimilco del 4 de diciembre de 1914. En la columna también se interpretaba el "aspecto lombrosiano de criminal nato" de Emiliano Zapata, aspecto físico que hacía temer sus intenciones de adueñarse del lugar que ocupaba Villa, la silla presidencial. En términos más fuertes, se refería a que la ocupación del Palacio enseñaba «la hez de un pueblo sumergida a la superficie en momentos de atroz confusión» y que era la representación del «triunfo de la más bárbara demagogia» ${ }^{33}$ (Figura 1). Es llamativa, en la nota del periódico, la referencia a Cesare Lombroso y la alusión implícita a la escuela de criminología positivista italiana.

31 «El dios de la guerra de los aztecas. La militarización de los antiguos mejicanos», El Tiempo, Bogotá, 2 de marzo de 1915, 2.

32 Sobre estos personajes se ha escrito mucho. Dos trabajos pueden resaltar: Womack, jr. Zapata; Frederich Katz, Pancho Villa. 2 tomos $2^{a}$. ed. (México: Ediciones Era, 2000).

33 «La anarquía en Méjico. Pancho Villa y Emiliano Zapata con sus amigos y secuaces en el Palacio de Gobierno de Méjico», El Tiempo, Bogotá, 21 de abril de 1915, 2. 


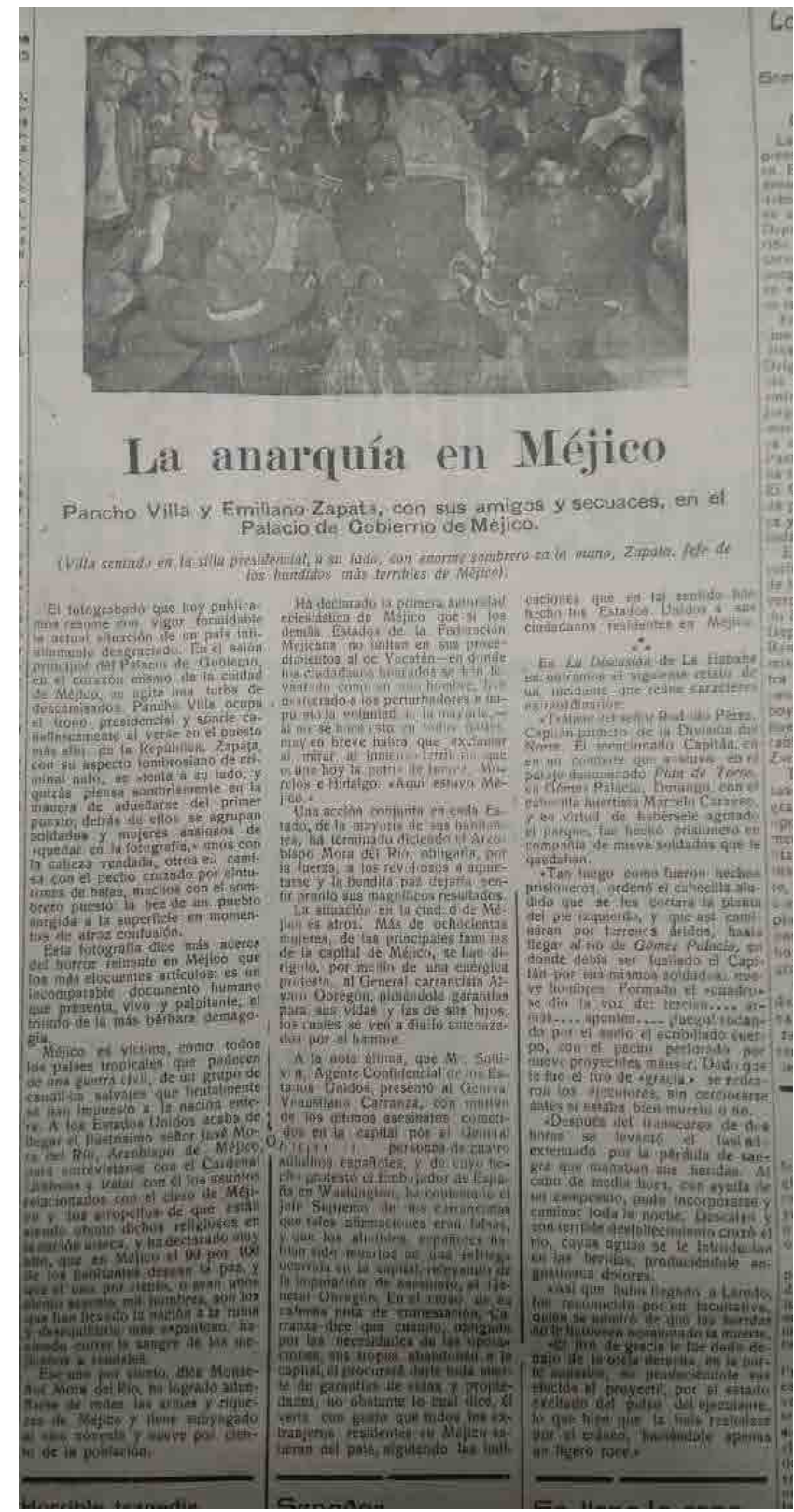

Figura 1. Columna «La anarquía en Méjico. Pancho Villa y Emiliano Zapata con sus amigos y secuaces en el Palacio de Gobierno de Méjico».

Fuente: El Tiempo, Bogotá, 21 de abril de 1915, 2. Repositorio: Biblioteca Nacional de Colombia, Bogotá, Colombia. 
Siguiendo con Zapata, desde muy temprano en la Revolución recibió calificativos muy fuertes. Era un «bandido» que había publicado un manifiesto en el que indicaba que mataría a «todos los ricos, y particularmente a los españoles» ${ }^{34}$. En ese orden de ideas, Zapata comenzó a ser denominado «el Atila del sur». Además de este apelativo, Zapata era uno de los «hombres más crueles y sanguinarios de los últimos tiempos» y su nombre era «pronunciado con horror, en casi todo el país». Además, Zapata, por sus «hechos horripilantes» era asemejado a «Nerón» ${ }^{35}$.

Se afirmaba que Zapata había establecido su poder en «la región tropical situada al sur de la Ciudad de México», es decir, como sabemos, en las tierras del Estado de Morelos de donde era oriundo. Además, se señalaba que, si bien pretendía mostrarse como portador de ideas humanitarias y de reforma agraria, «no hay tal cosa». Era "un simple bandido» que quería obtener «de su profesión el mayor provecho posible» ${ }^{36}$.

En cuanto a Pancho Villa se indicaba que era un tirano que había instaurado en la mitad del país un sistema de proscripción y robo, y que en la guerra ningún revolucionario había sido «más feroz, más implacable, más sanguinario» ${ }^{37}$. Para 1914 ya se le conocía por sus "variadas fechorías», calificándosele como "caudillo sanguinario» ${ }^{38}$. A pesar de poseer una "personalidad magnética», Villa tenía antecedentes penales que dejaban

34 «Méjico», El Liberal, Bogotá, 3 de octubre de 1911, 3. De aquí en adelante cuando se habla de bandidos o bandoleros, salvo contadas excepciones, no se alude a los bandidos sociales que si bien son proscritos por el Estado permanecen dentro de la sociedad campesina y son considerados por esta como héroes, luchadores o vengadores, tal como los define Eric Hobsbawm. Por el contrario, son tratados como hampones sin causas sociales. Véase Eric Hobsbawm, «Cuando los campesinos se vuelven bandidos,» en Sobre América Latina. Viva la Revolución (Bogotá: Crítica, 2018), 143-157.

35 «¿Quién es Zapata?», El Tiempo, Bogotá, 23 de enero de 1914, 2; «Los amos de Méjico», El Liberal, Bucaramanga, 21 de febrero de 1914, 3.

En el periódico mexicano El Imparcial, Zapata comenzó a ser calificado como el «moderno Atila». Véase: Ariel Rodríguez Kuri, «El discurso del miedo: El Imparcial y Francisco I. Madero,» Historia Mexicana Vol. 40, nº 4 (1991): 709. Como vemos, ese calificativo comenzó a ser empleado también más allá de las fronteras mexicanas.

36 «Los hombres de Méjico», El Tiempo, Bogotá, 1 de noviembre de 1915, 2.

37 «El "General" Pancho Villa», El Tiempo, Bogotá, 19 de diciembre de 1913, 2.

38 «Pancho Villa», El Liberal, Bogotá, 23 de febrero de 1914, 4. 
«bastante que desear» ${ }^{39}$. Era un delincuente cuyas tropas en la toma de ciudades como Juárez, «se dedicaron, como es costumbre, a celebrar tan importante victoria a la usanza mexicana: orgías, saqueos, satisfacer a sus anchas sus odios y pasiones con gentes de las altas clases sociales, encarcelando o fusilando a todo oficial enemigo que encontraban ya herido o prisionero» ${ }^{40}$. Ante una pregunta sobre cuánto durarían la «matanza, el pillaje y la destrucción de las propiedades», Villa respondió que dependería de la resistencia de Victoriano Huerta en el poder, pues continuarían la guerra «cueste lo que costare ${ }^{41}$. Esto hacía referencia a la guerra que enfrentaba al ejército federal contra los ejércitos revolucionarios después de la Decena Trágica, en febrero de 1913, cuando el presidente Madero y el vicepresidente Pino Suárez fueron obligados a renunciar y después fueron asesinados.

Así mismo, a Villa se le denominó «bandolero empedernido» y se aseguraba que desde el episodio en que había asesinado a su cuñado "empezó su vida de forajido y merodeador» ${ }^{42}$. De igual manera, se anotaba que el líder del ejército rebelde era el «notorio bandido y filibustero Pancho Villa, el audaz y ambicioso rufián ${ }^{43}$.

La historia del asesinato del cuñado de Villa por este, y de cómo allí comenzó su vida de bandido, se relató de la siguiente manera en la prensa colombiana. El padre de Villa murió, lo que lo obligó a hacerse cargo de su madre y de una hermana «un poco envanecida de su belleza e inclinada a la coquetería» ${ }^{44}$. Ella desapareció raptada por el juez del distrito. Villa se armó

39 «Los amos de,» 3.

40 C.Z., «Nuevos datos sobre Pancho Villa. La barbarie mejicana», El Tiempo, Bogotá, 2 de abril de 1914, 2.

Aunque también apareció una nota en la que se indicaba que Villa era un héroe, «hombre extraordinario que ha salido del pueblo, del montón anónimo, o sea de la inmensa legión de infelices peones que pueblan los campos de México». Cfr. R. Narváez Rivera, «Figuras tropicales. Un nuevo aspecto de Pancho Villa. De peón a General en Jefe», El Tiempo, Bogotá, 18 de marzo de 1914, 2.

41 «Méjico», El Liberal, Bogotá, 2 de febrero de 1914, 2.

42 «Pancho Villa. El hombre y el soldado», La Tribuna, Bogotá, 10 de julio de 1914, 3. 43 «Pancho Villa,» 3.

44 «El General Pancho Villa (Guerrillero mejicano)», El Liberal, Bogotá, 26 de abril de 1913, 4 . 
de su carabina y acompañado del juez persiguió a la pareja, la encontró, celebraron el matrimonio, ordenó al esposo redactar el testamento y lo acribilló: «Semejantes tragedias no son raras en Méjico ni siempre tienen sanción legal» ${ }^{45}$. Se afirmaba que los policías rurales intentaron detener a Villa pero él asesinó al jefe de la misión por lo que huyó a las montañas en donde vivió varios años. Escapó a emboscadas y a la recompensa que se ofrecía por él. Entre las sierras de Durango y Chihuahua se dedicó al bandidaje: "pilló fincas, arrebató rebaños y desbalijó viajeros, cada vez que la ocasión se presentaba» ${ }^{46}$.

Así como se relataba el asesinato del cuñado de Villa, también se anotaba que este había raptado a una mujer para casarse con ella. En un par de periódicos, uno de Barranquilla y otro de Bucaramanga, se afirmaba que «bastante se ha contado acerca de las barbaridades de Pancho Villa» pero no de cómo "se apoderó de su novia»" ${ }^{47}$ La muchacha, cuyo nombre no se menciona, y que trabajaba como cajera, era "muy hermosa", encantó a Villa pero fue "desdeñosa» con él ${ }^{48}$. Posteriormente ella fue raptada y llevada al hotel en donde Villa se alojaba. Allí, «pronto apareció éste, muy satisfecho con su traje nuevo, acompañado de un sacerdote y de la autoridad civil del caso, cuyos servicios había solicitado para que se le uniese con vínculo indisoluble a la desconsolada muchacha» ${ }^{49}$. Es decir, se quería mostrar que Villa era un ladrón consumado, tanto que hasta había raptado a una mujer para casarse con ella.

En febrero de 1915 un periódico de Medellín informaba que Villa había contratado, "por una cifra enorme», al campeón mundial de boxeo, «el temible Johnson», para una

\footnotetext{
45 «El General Pancho,» 4.

46 «El General Pancho,» 4.

47 «Cómo se casó el general Villa», El Liberal, Bucaramanga, 18 de abril de 1914, 2; "Cómo se casó Pancho Villa», El Nuevo Diario, Barranquilla, 20 de mayo de 1914, 2.

48 «Cómo se casó el,» 2.

49 «Cómo se casó el,» 2.

Más allá de la verdad de la información, Villa tuvo muchas compañeras sentimentales. Algunos afirman que sumaron 75 , aunque pocas fueron las reconocidas, después de su asesinato en 1923, como viudas oficiales. Véase Katz, Pancho Villa, Tomo II 385389; También se le acusaba de violaciones, pero él lo desmentía: John Reed, México insurgente (México: grupo Editorial Tomo, 2010), 361-363.
} 
pelea en Ciudad Juárez: «Esto es precioso!». Se afirmaba con ironía, «Pancho Villa viendo pelear a dos bárbaros!». La nota era una crítica al que llamaban el "rey de la sangre», quien según el medio impreso llevaba varios años haciendo derramar sangre "por montones en su desventurada patria». También se afirmaba que el boxeo tenía normas de respeto "que el sanguinario Pancho Villa no conoce ni por el forro». Al final, el periódico concluía que era posible que «el indio Villa le aprenda algo de civilización al negro Johnson", o que ambos se pongan a pelear: "Ahí sí había pelea!» ${ }^{50}$.

En otra nota se afirmaba que el poeta peruano José Santos Chocano, autor de Los cantos del Pacífico y Alma América, escribió en un periódico de Nueva York, afirmando que Pancho Villa, «el feroz cabecilla mejicano», creía ser «la Madre de Dios». Según Chocano, Villa era un personaje como Bolívar o Napoleón. En la nota se indicaba que Chocano fue huésped de Villa, por lo que era "posible que haya sacado el poeta del Rimac un buen lote de asignados y buen número de alhajas regaladas por su semidios». Así las cosas, según el autor de la nota, la relación entre Chocano y Villa era la de uno para el otro $^{51}$. Pablo Yankelevich muestra la forma como Chocano se relacionó con México durante la Revolución. Estuvo en Ciudad de México en la Decena Trágica, criticó a antiguos miembros del porfiriato y fue deportado a Europa por Victoriano Huerta. Desde Cuba y Puerto Rico apoyó la Revolución y asumió un rol antiimperialista. Conoció a Villa en marzo de 1914, en Torreón, y se sintió fascinado por aquél, aunque lo mismo, y más, sentía por Carranza. Sin embargo, en la fractura entre Villa y Carranza decidió apoyar al primero, por lo menos hasta las derrotas militares de Celaya a mediados de 1915. Y, en efecto, sí recibió dinero de Villa pero también lo había hecho de Carranza. Cuando ya no recibió más recursos de Villa,

50 «Pancho Villa quiere ver pelear a Johnson», El Espectador, Medellín, 24 de febrero de 1915, 1. Sobre esta información se ha dicho que lo que quería Villa, siendo gobernador interino de Chihuahua, era darle asilo a Johnson, pugilista negro que huía de la persecución del Ku Klux Klan.

51 «Pancho Villa, semidiós», El Espectador, Medellín, 13 de enero de 1916, 3. 
Chocano lo comenzó a pintar como un asesino despiadado, lo que le valió volver a servir al carrancismo ${ }^{52}$.

Cuando las fuerzas villistas ya estaban enfrentadas al ejército constitucionalista, liderado por Venustiano Carranza, la imagen del «centauro del norte» no cambiaba mucho. Sobre él se preguntaba Ernesto Murillo si era por «ventura un cabecilla honrado». La respuesta era un tajante no. Villa era un «indio inculto y brutal, quien poco en mira tiene la majestad de la República y solo atiende a sus intereses personales y de banda ${ }^{53}$. Villa no era indio. Era mestizo. La palabra «indio» se emplea como insulto, y muestra la carga peyorativa que contenía.

En julio de 1916, Andrés Merado escribía desde Anserma, población del departamento de Caldas, que Villa y sus tropas enfrentaban a las tropas estadounidenses, y la derrota de estas había sido «la más gloriosa epopeya de su enunciación al pandillaje». De tal manera que Villa, a quien tenían por "vulgar asesino», se había convertido en "héroe» porque defendió a México del invasor norteamericano, el cual, después de expoliar a Colombia, dirigió sus "fauces sombrías» contra aquel país: «Dios y ella le han perdonado -refiriéndose a Villa- por eso. Nosotros también. El Bronce será su más sublime apoteosis» ${ }^{54}$. Lo curioso es que año y medio antes, en otro periódico, Villa no era el héroe defensor contra Estados Unidos, sino que era visto como "hombre sin instrucción que por muchos años ha tenido la carrera de bandolero y es responsable de innumerables muertes, robos y rapiñas», y era patrocinado por el presidente Woodrow Wilson. Así las cosas, según ese impreso, Villa era una pieza de los Estados Unidos en su afán de saciar sus «concupiscencias políticas» ${ }^{55}$.

52 Pablo Yankelevich, «Vendedor de palabras. José Santos Chocano y la Revolución Mexicana,» Desacatos [versión on line], 4 (2000).

53 Ernesto Murillo, «La guerra yanqui azteca», Instantáneas, Bogotá, 6 de julio de 1916, 2. Cursivas en el texto.

54 Andrés Merado, «Los chacales en Méjico», La Opinión, Riosucio, 16 de agosto de $1916,3$.

55 «Ecos de Méjico ¿Quién es Villa?», La semana católica, Cali, 6 de febrero de 1915, 324. 
Un aspecto sobre el cual los periódicos informaban constantemente era sobre el arresto, las heridas o la muerte de Pancho Villa. Se indicaba que las informaciones se brindaban sin mayor sustento a la espera de confirmaciones oficiales. Esto muestra cierta obsesión porque Villa fuese sacado del escenario revolucionario. En la primera parte de 1915 se informaba que después de varios combates, Villa estaba «derrotadísimo» y en «malas condiciones»" ${ }^{56}$. En enero de 1916, en un periódico de Medellín, se informaba oficialmente que Villa había sido arrestado ${ }^{57}$. Un día después circuló la misma noticia en Bogotá ${ }^{58}$. Aunque unos días antes, desde El Paso, se informaba que Villa había sido asesinado por uno de los suyos en la Sierra Madre, "pero esta noticia no ha sido confirmada» ${ }^{59}$.

Dos meses después se reproducía un presunto decreto en donde Venustiano Carranza, como primer jefe del ejército constitucional, "y en vista de los horrorosos crímenes cometidos por bandas de bandidos en diferentes partes de la República ${ }^{60}$, y por el reciente ataque a un tren a ocho kilómetros de Santa Isabel por órdenes de Pancho Villa, lo condenaba a muerte. El decreto indicaba que cualquiera podía ejecutar la sentencia, siempre y cuando explicara cómo lo había hecho. En el periódico se afirmaba que Villa había sido "querídisimo amigo y compañero de revolución» de Carranza, dando a entender la ironía de la sentencia a muerte ${ }^{61}$.

En medio de la expedición punitiva llevada a cabo por tropas estadounidenses contra Villa y sus hombres como retaliación a la incursión que aquellos hicieron al pueblo de Columbus, Nuevo México, el 9 de marzo de 1916, las noticias sobre la situación de Villa, eran continuas. Más de un mes después se informaba que en un combate con tropas estadounidenses,

56 «Todavía Méjico», El Liberal, Bogotá, 31 de marzo de 1915, 2.

57 «Es apresado el famoso caudillo mejicano Pancho Villa», El Espectador, Medellín, 24 de enero de 1916, 3.

58 «Pancho Villa prisionero», El Espectador, Bogotá, 25 de enero de 1916, 3.

59 «Villa asesinado», El Espectador, Bogotá, 6 de enero de 1916, 3.

60 «La cabeza de Pancho Villa a precio», El Espectador, Medellín, 21 de marzo de 1916, 3 .

61 «La cabeza de,» 3. 
Villa había sido herido en la cadera e imposibilitado para continuar en combate $^{62}$. Pocos días después, en el mismo periódico de Medellín, se anunciaba, de manera no oficial, que Villa había muerto ${ }^{63}$. En una noticia, que venía desde Nueva York, se indicaba que el comandante de las tropas de Estados Unidos no suspendería operaciones militares hasta no comprobar la muerte de Pancho Villa, pues creía «que la noticia de su fallecimiento [obedecía] a un plan para distraer su atención» ${ }^{64}$.

En cuanto a la captura de Villa, sucedía algo similar, es decir, que era un rumor creado por los mismos mexicanos con el objetivo de «despistar» ${ }^{65}$. Aunque a mediados de 1916 se indicaba que la captura de Villa era inminente, sobre todo por las continuas derrotas que su ejército estaba sufriendo ${ }^{66}$. Finalizando 1916, la noticia que circulaba era que, en un combate en Chihuahua, Pancho Villa había sido gravemente herido ${ }^{67}$.

Para finalizar este recuento sobre Pancho Villa, queremos relacionar una nota que muestra la parte mítica del personaje. Desde la ciudad de Santa Marta, ubicada en la Costa Caribe colombiana, se afirmaba que tenían noticias de que Villa se encontraba en esa ciudad: “¿Será cierto? Puede, no puede. Bueno, si puede y no puede hay que buscarlo y no buscarlo», se indicaba. Pero qué pasaría si lo encontraban. Una opción era «entregarlo a los yankees que desean tenerlo entre sus brazos para saciar con él un apetito de patriotismo que se les está indigestando con los europeos; pues han ofrecido por su

62 «La Guerra yanqui mejicana-Derrota de los mejicanos-Pancho Villa herido», $E l$ Espectador, Medellín, 3 de abril de 1916, 3.

63 «Otra muerte de Pancho Villa», El Espectador, Medellín, 14 de abril de 1916, 3.

64 «La campaña contra México no se suspende», El Espectador, Bogotá, 19 de abril de 1916, 3 .

65 «Los yanquis seguirán dentro de territorio mejicano en persecución de Pancho Villa», El Espectador, Medellín, 15 de abril de 1916, 3.

66 «Próxima captura de Pancho Villa», El Espectador, Medellín, 28 de julio de 1916, 3. 67 «Pancho Villa gravemente herido», El Espectador, Medellín, 27 de noviembre de 1916, 3. Katz muestra, en su biografía de Villa, la forma como Villa se transformó de líder revolucionario nacional a guerrillero y bandido después de las derrotas del Bajío. Katz, Pancho Villa. Tomo II, 127-170. 
criminal cabeza -bien sea viva o en escabeche- la friolera de

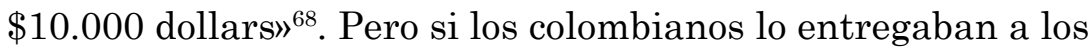
estadounidenses aparecía el dilema sobre lo que había pasado recientemente con el tratado que, por veinticinco millones de dólares, quería resarcir la separación de Panamá, «por la mutilación de nuestro territorio y por ende de nuestro escudo y bandera ${ }^{69}$. Debido al trato que Colombia había recibido de Estados Unidos por la expoliación de Panamá, la respuesta sobre la suerte de Villa parecía fácil: «Pero no, aún cuando se trata de un bandido, de una fiera, no serán los colombianos los que le den a los yankees esa gran satisfacción de que extirpen entre sus manos a su digno discípulo Pancho, para saciar una venganza. No y mil veces no» ${ }^{70}$. Lo relevante de esta nota es cómo, ante la hipotética captura de Villa en territorio colombiano, esta situación se relacionaba con la pérdida de Panamá y con el espíritu antiestadounidense que ese acontecimiento pudo engendrar en parte de la opinión pública colombiana.

\section{El pueblo revolucionario}

El pueblo que militaba en los ejércitos revolucionarios era visto, la mayoría de las veces, como salvaje. Sobre él se aplicaban calificativos racistas y clasistas. Se le describía como un cuerpo amorfo al que era necesario temerle. Esto fue constante a lo largo de la Revolución mexicana. Es decir, afloraba el miedo al pueblo.

Una vez fue aceptada la renuncia de Porfirio Díaz a la presidencia, y asumió el poder Francisco León de la Barra, se afirmaba que hubo manifestaciones pacíficas a favor de Francisco I. Madero, pero algunos se comportaron como «salvajes y vandálicos» ${ }^{71}$.

68 «El feroz guerrillero mexicano Pancho Villa en Santa Marta. Es curioso y fácil de suceder, ¿por qué no?», El Fígaro, Santa Marta, 9 de abril de 1916, s.p.

69 «El feroz guerrillero,» s.p.

70 «El feroz guerrillero,» s.p. El tratado al que se aludía es el Urrutia-Thompson del 6 de abril de 1914 por el que se resarcía, económicamente, la separación de Panamá en 1903.

71 «Méjico», El Liberal, Bogotá, 30 de mayo de 1911, 3. 
En un periódico de Medellín se lamentaban por la situación mexicana que parecía una cadena continua de levantamientos armados: "a los zapatistas los pasan por las armas y no pasa día que no nos anuncie nuevos hechos de armas. iSi serán personas!» ${ }^{72}$. Esta última exclamación debería ser entendida, por el mal manejo de los signos de puntuación, como una pregunta: ¿sí serán personas? Días después, en el mismo periódico, se afirmaba que, en medio de la guerra, los mexicanos se estaban matando "como chinches», debido a que tenían como gobernantes a hombres ambiciosos en lugar de hombres con "sentimientos nobles y cristianos» ${ }^{73}$.

La idea era mostrar al pueblo mexicano como bárbaro dirigido por criminales, refiriéndose a los líderes revolucionarios. En ese orden de ideas se reprodujo un discurso del diputado mexicano Francisco Bulnes durante la discusión de un proyecto de ley sobre pie de fuerza, el 15 de noviembre de $1911^{74}$. Sobre ese discurso se hicieron algunas reflexiones como por ejemplo que los hechos violentos obedecían no a principios democráticos sino a "guerras de razas», siendo la situación de México caracterizada como una «reivindicación de razas» o "reivindicación de la barbarie contra la paz». En ese orden de ideas, quienes luchaban por defender y rescatar sus derechos, como los zapatistas, eran calificados como mezcla de indio y zambo, y por ello mismo, bárbaros. Las ideas del movimiento revolucionario provenían de una «temible subespecie humana» y soplaban "como huracán en el espíritu rudo, misterioso y sombrío de los indígenas de los Estados de México, Puebla, Oaxaca y Guerrero». Así, la Revolución era una farsa guiada por «seis y ocho profesionistas refugiados en los Estados Unidos», sumados a "un puñado de jefes de guerrilla, un tropel ruidoso de demagogos, hábiles en el arte de la agitación, y una gran masa de chusmas armadas

72 «Notas internacionales», La Buena Prensa, Medellín, 22 de marzo de 1912, 9. 73 «Notas internacionales», La Buena Prensa, Medellín, 10 de mayo de 1912, 9.

74 La discusión giró en torno al tamaño del ejército. Para Bulnes se requería un soldado por cada 300 habitantes. Mario Ramírez Rancaño, «Ejército federal, jefes políticos, amparos, deserciones: 1872-1914,» Estudios de Historia Moderna y Contemporánea de México, n 47 (2014): 47, DOI: http://dx.doi.org/10.1016/S01852620(14)70334-2. 
y desarmadas». Para que la Revolución funcionara, según Bulnes, faltaba "su elemento aristocrático, el necesario para fundar el nuevo Gobierno, faltándole el elemento conservador, represor del elemento revolucionario indefinido» ${ }^{75}$. De tal forma que el movimiento revolucionario debería mezclar una parte pequeña de lo radical con el elemento conservador, el cual serviría de guía para que los acontecimientos no se desbordaran.

Posteriormente se informaba que en un tren que se dirigía a Cuernavaca, actual Estado de Morelos, los zapatistas «mataron a las mujeres y a los niños, les cortaron los dedos para apoderarse de los anillos, y se robaron todo lo demás que hallaron a mano» ${ }^{76}$. Desde Chihuahua se indicaba que "dos bandidos» habían ingresado a la casa del estadounidense Stevens, "con malos propósitos», pero las hijas de él se defendieron y dieron de baja a uno de ellos ${ }^{77}$. En Toluca, Estado de México, se afirmaba no solo que los zapatistas mataron a más de ochenta federales, sino que un zapatista entró a una casa, le arrebató un niño a la madre "para golpearlo contra un guayacán hasta despedazarle el cráneo. Semejante escena volvió loca de remate a la madre del niño" ${ }^{78}$. Comenzando 1913 se indicaba que el pueblo de San Marcial, Sonora, había sido destruido por «los indios», quienes habían "matado a muchas personas y parece que entre éstas no faltaban yanquis», por lo que era previsible que Estados Unidos metiera la «nariz» en el conflicto mexicano ${ }^{79}$.

75 «La situación política de Méjico», El Tiempo, Bogotá, 9 de junio de 1912, 2.

No se hizo ninguna referencia a quién era Bulnes, reconocido porfirista, quien para ese momento ya podría ser considerado un historiador "revisionista", sobre todo por sus obras sobre Juárez: El verdadero Juárez y La verdad sobre la intervención y el imperio. Es de anotar, como lo muestra Rodríguez Kuri, que Bulnes se esmeró por construir un acervo documental sobre el gobierno de Díaz y sobre la revolución maderista, así como sobre las condiciones económica, política y social de México. Véase: Ariel Rodríguez Kuri, "Francisco Bulnes, Porfirio Díaz y la Revolución maderista,» Estudios de Historia Moderna y Contemporánea de México, n 13 (1990): 187-202.

76 «Méjico», El Liberal, Bogotá, 20 de agosto de 1912, 2.

77 «Méjico», El Liberal, Bogotá, 7 de septiembre de 1912, 2.

78 «Méjico», El Liberal, Bogotá, 12 de octubre de 1912, 3.

79 «Notas internacionales», La Buena Prensa, Medellín, 8 de enero de 1913, 13. 
La situación era tal que alguien se preguntaba, «estremecido de horror», si México era una república o «un 'bajalato' turco, o si es, como ha dicho un periódico inglés, un matadero humano». La imagen que se tenía del país era, más o menos así: «prisión, proscripción, muerte, extrañamiento del país, embargo o secuestro de bienes» ${ }^{80}$.

En una nota se afirmaba que la barbarie que padecía México era como la de las «tribus antropófagas» ${ }^{81}$, para dar a entender el nivel de degradación del conflicto. De esa degradación no se salvaban las mujeres. Se afirmaba que muchas habían optado por actuar, vestirse y combatir como los hombres. Una de ellas peleaba "como un demonio» y disfrutaba viendo la ejecución de los prisioneros del ejército federal. Esto se debía a que, a Torreón, donde vivía, llegó el ejército y asesinó a su madre y hermana ${ }^{82}$.

Para un periódico conservador y católico, era claro que las «manifestaciones de salvajismo y poco respeto a la Religión, a la propiedad y el derecho ajeno», que se veían en la Revolución mexicana, eran muestra de que pueblos como México no podían existir "más que bajo la férrea mano del dictador», o de lo contrario, estaban "llamados a desaparecer envueltos con las cadenas de esclavo impuestas por el conquistador» ${ }^{83}$. Aquí se introducen dos elementos. El primero es el de indicar que pueblos atrasados como México y Colombia requerían de gobernantes de mano fuerte. Esto fue notorio a comienzos de la Revolución cuando en la prensa colombiana aparecían notas y columnas alabando a Porfirio Díaz e indicando que Colombia requería un gobernante de ese talante. Este artículo no trata de ese punto, el cual será abordado en otros textos. El segundo aspecto es el religioso, porque se afirmaba que la Revolución era ejemplo del irrespeto a la religión y a Dios.

80 «La situación de Méjico», Gil Blas, Bogotá, 3 de noviembre de 1913, 2.

81 Ciprián Pericles, seudónimo, «Causas de la guerra en México», El Liberal, Bogotá, 26 de diciembre de 1913, 2.

82 «Las mujeres en la guerra civil de Méjico», El Liberal, Bogotá, 24 de febrero de 1914,1 .

83 «La religión y la guerra. El fin de Méjico», Azul, Buga, 24 de diciembre de 1914, $2-3$. 
Como ejemplo de lo anterior se afirmaba que «el mismo santuario de Nuestra Señora de Guadalupe» había sido objeto de «los sacrílegos atentados de los villistas, y a tal punto ha llegado el terror de todas las personas honradas, que aun las más patriotas consideran la intervención armada de los Estados Unidos como una solución salvadora» ${ }^{84}$. El periódico bugueño no caía en cuenta que un año antes, en abril de 1914, tropas estadounidenses habían invadido el puerto de Veracruz, permaneciendo allí hasta noviembre de ese año.

Siguiendo con el tema anterior, se afirmaba que los responsables de este estado de cosas eran el liberalismo y la masonería. Se indicaba que esta última se había dado cuenta de que Victoriano Huerta invocaba "la asistencia de Dios para devolver la paz a la nación», por lo que usó la violencia revolucionaria para sacarlo del poder ${ }^{85}$. Otro ejemplo que se mostraba era en el que se informaba que los zapatistas le exigían al obispo de Chiapas 5000 dólares de chantaje o sería crucificado el viernes santo. Se aseguraba «que el obispo está muy pobre y que por consiguiente será crucificado» ${ }^{86}$. Obviamente el obispo Francisco Orozco y Jiménez no fue crucificado, aunque sí tuvo, como muchos prelados, que salir al exilio. El caso de Chiapas muestra los roces entre la Iglesia católica y grupos revolucionarios, algunos de los cuales emplearon medidas anticlericales ${ }^{87}$.

84 «Méjico liberal», Azul, Buga, 1 de abril de 1915, 3. Contraria a esta actitud proestadounidense, otro periódico católico hablaba, seguramente cargado de espíritu antiprotestante, de los «mercaderes yankees» que serían derrotados en suelo mexicano, lo que le permitiría a México escribir «páginas sublimes de heroísmo, epopeyas soñadas, hechos más dignas aún, que los llevados a cabo por los soldados de la turbulenta Europa», El Baluarte, Chiquinquirá, 5 de junio de 1916, 2.

85 «En Méjico», El cometa, Popayán, 26 de marzo de 1915, 1.

En un periódico bumangués se afirmaba que en Colombia las logias masónicas eran «ruda y torpemente atacadas en la prensa clerical, en los púlpitos, en los confesionarios etc». «La masonería y el clero mejicano», El Liberal, Bucaramanga, 30 de mayo de 1914, 2.

86 «Méjico», El Liberal, Bogotá, 11 de abril de 1914, 2.

87 Miguel Lisbona Guillén, «Los inicios de la política anticlerical en Chiapas durante el período de la Revolución (1910-1920),» Historia Mexicana Vol.57, n² 2 (2007): 491530. 
El asunto relevante es que simultáneamente, en varios periódicos colombianos, al mostrarse la barbarie mexicana de la Revolución relacionándola con el irrespeto a la religión, se indicaba que esa situación debería ser tomada como ejemplo para Colombia. En uno de ellos se preguntaba si «¿le gustaría al pueblo liberal que se dice católico una imitación de todo eso en Colombia?», para responder que "estamos por creerlo así», debido a la "obstinación con que se mantiene en el error y trabaja por el triunfo de sus conductores, entre los cuales hay no pocos discípulos aventajados de los bandidos mejicanos» ${ }^{88}$. Es decir, se creía que los dirigentes del liberalismo colombiano querían imitar el ejemplo de Zapata y Villa. En otro periódico eran contundentes al afirmar: "iQué lecciones tan elocuentes, aunque dolorosas, nos da el liberalismo en Méjico a los católicos de Colombia! No las miremos con indiferencia y estemos siempre en guardia contra el enemigo» ${ }^{89}$. El enemigo, al mejor estilo decimonónico, era el liberalismo, el cual había sido condenado desde mediados del siglo XIX por Pío IX.

1915 fue un año de cruenta guerra civil en México ${ }^{90}$. Esto se ve reflejado en las informaciones que se brindaban en los periódicos colombianos. Parecía que a lo largo y ancho de México el caos y la anarquía reinaban. «En Guaymas y Hermosillo la muchedumbre se dedica a saquear el comercio», decía una nota en dos periódicos diferentes ${ }^{91}$. Desde Ciudad de México se informaba que las tropas zapatistas habían ingresado a la ciudad, saqueando almacenes, entre ellos la Casa Inglesa, y además asesinaron a un «notable ciudadano yanqui», el señor Wanas ${ }^{92}$.

Desde El Paso se informaba que en el norte de México reinaba el «terror», debido al peligro por una posible «invasión

88 «Méjico liberal», Azul, Buga, 11 de febrero de 1915, 2-3.

89 «En Méjico», El cometa, Popayán, 26 de marzo de 1915, 1.

90 Sobre la guerra en ese año véase Salmerón, 1915; Berta Ulloa, Historia de la Revolución mexicana, período 1914-1917. La encrucijada de 1915 (México: El Colegio de México, 1979).

91 «El desastre mejicano», El Correo Liberal, Medellín, 10 de abril de 1915, 3; «Los incansables mejicanos. Atropellos, saqueos y bombardeos», El Liberal, Bogotá, 10 de abril de 1915, 2 .

92 «Saqueo de los zapatistas», El Espectador, Medellín, 16 de marzo de 1915, 3. 
por las hordas revolucionarias mejicanas» ${ }^{93}$. También se infirmaba que

después de saciar sus instintos sanguinarios y su sed de rapiña; después de violar mujeres y asesinar hombres de distintas nacionalidades, y después de arrojar a la cárcel, torturar y robar a sus dueños, las cohortes de desalmados y bárbaros zapatistas y carrancistas aplicaron la tea incendiaria a todo cuanto hallaron a mano ${ }^{94}$.

En cuanto al ferrocarril, se afirmaba que:

por los rieles brillantes que el oro extraño tendió sobre los dominios de Porfirio, no cruzan ya las máquinas trepidantes, sino las hordas feroces de los Villas, de los Zapatas, de los Orozcos, de los mil bandoleros que se disputan con el filo de sus machetes los despojos lacerados de México ${ }^{95}$.

Con el paso del tiempo las noticias e informaciones de este tipo no mermaban. En una de ellas se indicaba que las tropas zapatistas habían devastado la región que dominaban, incendiado a su paso varias poblaciones ${ }^{96}$. En este orden de ideas, México corría "veloz a su descomposición física y moral $»^{97}$. Lo anterior se reflejaba en que México vivía una de las revoluciones "más desastrosas»: «iCuántas lágrimas vertidas por madres, viudas y huérfanos! ¡Cuántas vidas segadas por el odio! ¡Cuánta desmoralización en las masas populares! ¡Cuánta riqueza destruida y cuánto retroceso efectuado en más de tres años de revuelta!» y todo, según el periódico, para nada ${ }^{98}$.

En 1916 se mostraban notas en los que se acusaba al villismo de cometer múltiples delitos. Se informaba, el 21 de septiembre, que el «bandido Pancho Villa», entró con dos mil

93 «Graves sucesos en México; témese una invasión mejicana al territorio yanqui: Carranza y Villa en desacuerdo», El Espectador, Medellín, 14 de agosto de 1915, 3. 94 «Pobre Méjico! Destrucción y pillaje», Renacimiento, Manizales, 5 de agosto de $1915,4$.

95 «Porfirio Díaz», La Patria, Bogotá, 6 de julio de 1915, 3.

96 «La guerra en Méjico», La Patria, Bogotá, 25 de mayo de 1915, 1.

97 «Notas internacionales», La Buena Prensa, Medellín, 21 de abril de 1915, 12. 98 «Notas internacionales», La Buena Prensa, Medellín, 9 de junio de 1915, 7. 
soldados a la ciudad de Chihuahua después de vencer a los carrancistas: «La ciudad fue entregada a una bárbara degollina y a un brutal saqueo». Los carrancistas contraatacaron, derrotaron, y recuperaron lo robado. Por su parte se aseguraba que «Pancho Villa logró escapar solamente con unos pocos compañeros ${ }^{99}$. En efecto, después de las derrotas en las batallas de El Bajío a mediados de 1915 el villismo entró en descomposición. De tal forma que muchas de las notas que aparecían sobre pillaje, a pesar del morbo, eran ciertas ${ }^{100}$.

La barbarie que se reflejaba en la Revolución mexicana también era responsabilidad del consumo de alcohol. Tomando una nota de El Diario de Panamá, se indicaba que «no detenernos a considerar los estragos del pulque en el pueblo mexicano, sería lo mismo que hablar del infierno sin nombrar a Satanás». En las zonas cálidas se consumía poco prefiriéndose el mezcal y el tequila, "productos alcohógenos no menos perjudiciales». Se indicaba que el pulque lo consumía el indio para contrarrestar las deficiencias alimenticias, de tal forma que se explicaba que el carácter de ese indio adquiría "manifestaciones de impulsiva temibilidad» y sus hijos venían al mundo con «los estigmas físicos y morales que distinguen al criminal nato» ${ }^{101}$.

El problema con el alcohol era tan fuerte que antes de que terminara el conflicto armado se implementaron campañas antialcohólicas (1916-1931) para buscar un «mejor país» en función de la «moralidad de la sociedad». Estas campañas también buscaban atacar a quienes se aprovechaban con los vicios de la población ${ }^{102}$.

99 «Chihuahua es entregada al saqueo y la degollina por Pancho Villa», El Espectador, Medellín, 22 de septiembre de 1916, 3.

100 Sobre este proceso véase: Knight, La Revolución, 1076-1117.

101 «Apuntes sobre Méjico», El Liberal, Bogotá, 24 de mayo de 1915, 1.

102 David Pulido Esteva, iA su salud! Sociabilidades, libaciones y prácticas populares en la Ciudad de México a principios del siglo XX (México: El Colegio de México, 2015), 109-138; Jesús Méndez Reyes, «De crudas y moralidad: campañas antialcohólicas en los gobiernos de la posrevolución (1916-1931),» en Cruda realidad. Producción, consumo y fiscalidad de las bebidas alcohólicas en México y América Latina. Siglo XVII-XX, coord. Ernest Sánchez Santiró (México: Instituto de Investigaciones Dr. José María Luis Mora, 2007), 243-271. 
En esencia, el pueblo, ya fuera por acción u omisión, parecía merecer su suerte. Se le veía como bárbaro, pero también como sumiso, y esta sumisión también parecía ser su culpa.

\section{Conclusiones}

Sabemos que se recomienda no citar en las conclusiones. Sin embargo, les pedimos acepten una excepción. Como primera conclusión creemos que la Revolución mexicana fue vista en Colombia como un mal ejemplo que no debería imitarse. En contravía, se pensaba que el país era ejemplo de paz y civilización. A pesar del convulsionado siglo XIX que había vivido, Colombia era el "pueblo fénix del mundo» ${ }^{103}$. Por el contrario, México, era "un estado salvaje casi inaudito" y se había convertido en referencia "para juzgarnos, de manera, claro está, más que desfavorable» ${ }^{104}$. Así las cosas, México proyectaba una pésima imagen que afectaba la lectura que, por ejemplo, sobre Colombia tenían en Europa.

La segunda conclusión es que el caudillismo y la barbarie que proyectaba la Revolución mexicana contrastaban con la imagen de país civilista, construida desde el siglo XIX, que permitía afirmar que en Colombia se había superado la etapa caudillista. Así, el país había aprendido a «conocer los falsos profetas y los lobos con piel de oveja» y a no dejarse engañar «con frases altisonantes y con penachos de guerrilleros tropicales» ${ }^{105}$. En ese sentido, nuestro país iría

modestamente al porvenir, sin fanfarronería ni baladronadas, sin sacudidas epilépticas ni luchas salvajes [...] nos destacaremos dentro de poco en el mar agitado de la América Latina como una isla apacible y hermosa, en que florecen todas las libertades al amparo de la paz y de la ley ${ }^{106}$.

Palabras llenas de seguridad, pero nada de ello ocurrió.

103 Ayres H. Nascimiento (periodista brasileño), «Colombia ante la América latina», El Liberal, Bogotá, 20 de julio de 1911, 6.

104 «Méjico», El Tiempo, Bogotá, 23 de enero de 1914, 2.

105 «Las guerras civiles en los trópicos», El Tiempo, Bogotá, 19 de diciembre de 1913, 2.

106 «El continente enfermo», El Tiempo, Bogotá, 9 de febrero de 1914, 2. Cursivas mías. 
Reforzando la idea anterior se indicaba que Colombia había superado «toda querella armada y todo desorden de caracteres bélicos» ${ }^{107}$, renunciando definitivamente a la "política tropical», con la que se caracterizaba a los gobernantes caribeños y centroamericanos. Se afirmaba que en Colombia todas las dificultades se superaban

para poder atender debidamente a nuestros problemas internos, para trabajar en nuestra regeneración y hacer que en esta tierra la democracia, la justicia y el progreso sean patentes realidades y no palabras aptas tan sólo para coger incautos y engañar a masas ignorantes ${ }^{108}$.

Cuando aparecían voces de solidaridad con México por lo que allí estaba pasando, sobre todo cuando se aludía a la intervención de Estados Unidos, y debido a que existían «casi idénticas heroicas tradiciones», venía al recuerdo "aquella indiferencia gélida con que Méjico miró nuestros dolorosos sucesos de Panamá» ${ }^{109}$. Es decir, cómo ser solidario con lo que pasaba en México si ese país no lo fue cuando Colombia perdió Panamá.

En contraste con todo lo anterior, una tercera conclusión nos muestra que la situación social de Colombia no distaba mucho de lo que había generado la Revolución. Vemos, por ejemplo, que un autor se hizo la siguiente pregunta: «¿Será verdad que nuestra cultura nos ha colocado en un nivel más alto que el que ocupa México?». La respuesta era no. Colombia padecía tantos problemas como los que tenía México, por lo que se hacía otra pregunta: «¿Por qué entonces nuestros legisladores no han abocado la resolución de los serios problemas que tenemos pendientes? ${ }^{110}$. Es claro que la idea de que Colombia era un país superior no estaba directamente ligada con la realidad. El país tenía muchos problemas de orden político, económico y social; sin embargo, el imaginario

107 «La prensa europea y la política colombiana», El Tiempo, Bogotá, 31 de marzo de 1914, 2 .

108 «La prensa europea,» 2.

109 «Apoyo a Méjico. Guerra entre Méjico y Estados Unidos», El Nuevo Diario, Barranquilla. 2 de abril de 1914, 1.

110 N.R., «Patriotismo mejicano», El Liberal, Bogotá, 13 de noviembre de 1913, 2. 
de que era civilista, de que sus gobernantes cumplían a rajatabla la ley, y de que distaban mucho, en cuanto a sus comportamientos, de los líderes revolucionarios mexicanos, había calado profundamente. Desde allí se juzgaba a la situación mexicana y, de paso, se podía opacar la discusión de los grandes problemas que Colombia padecía.

\section{Referencias}

\section{Fuentes Primarias}

\section{Publicaciones Periódicas}

«A vuelo de pájaro, Méjico». El Debate, Barranquilla, 6 de noviembre de 1912.

«Apoyo a Méjico. Guerra entre Méjico y Estados Unidos». El Nuevo Diario, Barranquilla. 2 de abril de 1914.

«Apuntes sobre Méjico». El Liberal, Bogotá, 24 de mayo de 1915.

«Causas de la guerra en México». El Liberal, Bogotá, 25 de febrero de 1914.

"Chihuahua es entregada al saqueo y la degollina por Pancho Villa». El Espectador, Medellín, 22 de septiembre de 1916.

«Cómo se casó el general Villa». El Liberal, Bucaramanga, 18 de abril de 1914.

«Cómo se casó Pancho Villa». El Nuevo Diario, Barranquilla, 20 de mayo de 1914.

«Ecos de Méjico ¿Quién es Villa?». La semana católica, Cali, 6 de febrero de 1915.

«El "General" Pancho Villa». El Tiempo, Bogotá, 19 de diciembre de 1913.

«El continente enfermo». El Tiempo, Bogotá, 9 de febrero de 1914.

«El desastre mejicano». El Correo Liberal, Medellín, 10 de abril de 1915. 
«El dios de la guerra de los aztecas. La militarización de los antiguos mejicanos». El Tiempo, Bogotá, 2 de marzo de 1915.

«El feroz guerrillero mexicano Pancho Villa en Santa Marta. Es curioso y fácil de suceder, ¿por qué no?». El Fígaro, Santa Marta, 9 de abril de 1916.

«El General Pancho Villa (Guerrillero mejicano)». El Liberal, Bogotá, 26 de abril de 1913.

«El problema de los indios». El Tiempo, Bogotá, 13 de abril de 1914.

«En Méjico». El cometa, Popayán, 26 de marzo de 1915.

«Es apresado el famoso caudillo mejicano Pancho Villa». El Espectador, Medellín, 24 de enero de 1916.

«Graves sucesos en México; témese una invasión mejicana al territorio yanqui: Carranza y Villa en desacuerdo». El Espectador, Medellín, 14 de agosto de 1915.

«La anarquía en Méjico. Pancho Villa y Emiliano Zapata con sus amigos y secuaces en el Palacio de Gobierno de Méjico». El Tiempo, Bogotá, 21 de abril de 1915

«La cabeza de Pancho Villa a precio». El Espectador, Medellín, 21 de marzo de 1916.

«La campaña contra México no se suspende». El Espectador, Bogotá, 19 de abril de 1916.

«La cuestión mejicana». El Liberal, Bogotá, 29 de abril de 1914

«La guerra en Méjico». La Patria, Bogotá, 25 de mayo de 1915.

«La Guerra yanqui mejicana-Derrota de los mejicanos-Pancho Villa herido». El Espectador, Medellín, 3 de abril de 1916.

«La masonería y el clero mejicano». El Liberal, Bucaramanga, 30 de mayo de 1914.

«La prensa europea y la política colombiana». El Tiempo, Bogotá, 31 de marzo de 1914.

«La religión y la guerra. El fin de Méjico». Azul, Buga, 24 de diciembre de 1914. 
«La situación de Méjico». Gil Blas, Bogotá, 3 de noviembre de 1913. «La situación política de Méjico». El Tiempo, Bogotá, 9 de junio de 1912.

«Las guerras civiles en los trópicos». El Tiempo, Bogotá, 19 de diciembre de 1913.

«Las mujeres en la guerra civil de Méjico». El Liberal, Bogotá, 24 de febrero de 1914.

«Los amos de Méjico». El Liberal, Bucaramanga, 21 de febrero de 1914.

«Los hombres de Méjico». El Tiempo, Bogotá, 1 de noviembre de 1915.

«Los incansables mejicanos. Atropellos, saqueos y bombardeos». $E l$ Liberal, Bogotá, 10 de abril de 1915.

«Los yanquis seguirán dentro de territorio mejicano en persecución de Pancho Villa». El Espectador, Medellín, 15 de abril de 1916.

«Méjico liberal». Azul, Buga, 1 de abril de 1915.

«Méjico liberal». Azul, Buga, 11 de febrero de 1915.

«Méjico y nosotros». El Tiempo, Bogotá, 28 de abril de 1914.

«Méjico». El Evangelista Cristiano, Bogotá, enero de 1914.

«Méjico». El Liberal, Bogotá, 11 de abril de 1914.

«Méjico». El Liberal, Bogotá, 12 de octubre de 1912.

«Méjico». El Liberal, Bogotá, 2 de febrero de 1914.

«Méjico». El Liberal, Bogotá, 20 de agosto de 1912.

«Méjico». El Liberal, Bogotá, 3 de octubre de 1911.

«Méjico». El Liberal, Bogotá, 30 de mayo de 1911.

«Méjico». El Liberal, Bogotá, 7 de septiembre de 1912.

«Méjico». El Tiempo, Bogotá, 23 de enero de 1914. 
«México». El Liberal, Bogotá, 24 de abril de 1911.

«Notas internacionales». La Buena Prensa, Medellín, 10 de mayo de 1912.

«Notas internacionales». La Buena Prensa, Medellín, 21 de abril de 1915.

«Notas internacionales». La Buena Prensa, Medellín, 22 de marzo de 1912.

«Notas internacionales». La Buena Prensa, Medellín, 8 de enero de 1913.

«Notas internacionales». La Buena Prensa, Medellín, 9 de junio de 1915.

«Otra muerte de Pancho Villa». El Espectador, Medellín, 14 de abril de 1916.

«Pancho Villa gravemente herido». El Espectador, Medellín, 27 de noviembre de 1916.

«Pancho Villa prisionero». El Espectador, Bogotá, 25 de enero de 1916.

«Pancho Villa quiere ver pelear a Johnson». El Espectador, Medellín, 24 de febrero de 1915.

«Pancho Villa, semidiós». El Espectador, Medellín, 13 de enero de 1916.

«Pancho Villa. El hombre y el soldado». La Tribuna, Bogotá, 10 de julio de 1914.

«Pancho Villa». El Liberal, Bogotá, 23 de febrero de 1914.

«¡Pobre Méjico! Destrucción y pillaje». Renacimiento, Manizales, 5 de agosto de 1915.

«Porfirio Díaz juzgado por William Ancher». El Tiempo, Bogotá, 17 de junio de 1913.

«Porfirio Díaz». La Patria, Bogotá, 6 de julio de 1915.

«Porfirio Díaz». La Tribuna, Bogotá, 5 de julio de 1915. 
«Próxima captura de Pancho Villa». El Espectador, Medellín, 28 de julio de 1916.

«¿Quién es Zapata?». El Tiempo, Bogotá, 23 de enero de 1914.

«Repartición de tierras en Méjico». El Liberal, Bogotá, 8 de junio de 1912.

«Saqueo de los zapatistas». El Espectador, Medellín, 16 de marzo de 1915.

«Situación de Méjico». El Liberal, Bogotá, 26 de septiembre de 1914.

«Todavía Méjico». El Liberal, Bogotá, 31 de marzo de 1915.

«Villa asesinado». El Espectador, Bogotá, 6 de enero de 1916.

C.Z. «Nuevos datos sobre Pancho Villa. La barbarie mejicana». El Tiempo, Bogotá, 2 de abril de 1914.

Ciprián Pericles, seudónimo. «Causas de la guerra en México». El Liberal, Bogotá, 26 de diciembre de 1913.

Maetzu, Ramiro de. «Lo de México». El Tiempo, Bogotá, 14 de mayo de 1913.

Merado, Andrés. «Los chacales en Méjico». La Opinión, Riosucio, 16 de agosto de 1916.

Murillo, Ernesto. «La guerra yanqui azteca». Instantáneas, Bogotá, 6 de julio de 1916.

N.R. «Patriotismo mejicano». El Liberal, Bogotá, 13 de noviembre de 1913.

Narváez Rivera, R. «Figuras tropicales. Un nuevo aspecto de Pancho Villa. De peón a General en Jefe». El Tiempo, Bogotá, 18 de marzo de 1914.

Nascimiento, Ayres H. «Colombia ante la América latina». El Liberal, Bogotá, 20 de julio de 1911.

\section{Fuentes secundarias}

Estadísticas históricas de México 2009. Aguascalientes: INEGI, 2010. 
Estados Unidos Mexicanos. Cien años de censos de población. Aguascalientes: INEGI, 1996.

Cortés Guerrero, José David. «Tolerancia religiosa e inmigración. México y Nueva Granada a finales de la década de 1840.» Anuario de Historia Regional y de las Fronteras Vol. 23, ${ }^{\circ}$ 2 (2018): 51-84. DOI: https://doi.org/10.18273/revanu.v23n22018002 .

Hobsbawm, Eric. «Cuando los campesinos se vuelven bandidos.» En Sobre América Latina. Viva la Revolución. Bogotá: Crítica, 2018.

Katz, Frederich. Pancho Villa. 2 tomos $2^{a}$. ed. México: Ediciones Era, 2000.

Knight, Alan. La Revolución mexicana. México: Fondo de Cultura Económica, 2010.

Lisbona Guillén, Miguel. «Los inicios de la política anticlerical en Chiapas durante el período de la Revolución (1910-1920).» Historia Mexicana LVII.2 (2007): 491-530.

Méndez Reyes, Jesús. «De crudas y moralidad: campañas antialcohólicas en los gobiernos de la posrevolución (19161931).» En Cruda realidad. Producción, consumo y fiscalidad de las bebidas alcohólicas en México y América Latina. Siglo XVII-XX, coordinado por Ernest Sánchez Santiró. México: Instituto de Investigaciones Dr. José María Luis Mora, 2007.

Pulido Esteva, David. ¡A su salud! Sociabilidades, libaciones y prácticas populares en la Ciudad de México a principios del siglo XX. México: El Colegio de México, 2015.

Ramírez Rancaño, Mario. «Ejército federal, jefes políticos, amparos, deserciones: 1872-1914.» Estudios de Historia Moderna y Contemporánea de México, 47 (2014): 41-78. DOI: http:// dx.doi.org/10.1016/S0185-2620(14)70334-2.

Reed, John. México insurgente. México: Grupo Editorial Tomo, 2010.

Rodríguez Kuri, Ariel. «El discurso del miedo: El Imparcial y Francisco I. Madero.» Historia Mexicana 40.4 (1991): 697-740. 
Rodríguez Kuri, Ariel. «Francisco Bulnes, Porfirio Díaz y la Revolución maderista.» Estudios de Historia Moderna y Contemporánea de México 13 (1990): 187-202.

Salmerón Sanginés, Pedro. «Los historiadores y la guerra civil de 1915. Origen y persistencia de un canon historiográfico.» Historia Mexicana 58.4 (2009): 1305-1368.

Salmerón Sanginés, Pedro. 1915. México en guerra. México: Planeta, 2015.

Turner, John Kenneth. México bárbaro. México: Grupo Editorial Tomo, 2010.

Ulloa, Berta. Historia de la Revolución mexicana, período 1914-1917. La encrucijada de 1915. México: El Colegio de México, 1979.

Von Mentz, Brígida. «Trabajo minero y control social durante el Porfiriato. Los operarios de dos poblaciones contrastantes.» Historia Mexicana, L.3 (2001): 555-607.

Womack jr., John. Zapata y la Revolución mexicana. $26^{a}$ ed. México: Siglo XXI Editores, 2004.

Yankelevich, Pablo. «Vendedor de palabras. José Santos Chocano y la Revolución Mexicana,» Desacatos [versión on line], 4 (2000).

\section{Citar este artículo}

Cortés Guerrero, José David. «"Matanza, pillaje y destrucción": aspectos sociales de la Revolución mexicana vistos desde Colombia, 1910-1917.» Historia Y MEMORIA, n 22 (2021): 245-284. DOI: https:/doi.org/10.19053/20275137. $\mathrm{n} 22.2021 .10878$. 